\title{
Deconstructing the Reporting of Hostage Taking in the Niger Delta
}

\author{
Chigozi Ijeomah ETI
}

\begin{abstract}
The pattern of reporting the January 11, 2006 incident of the kidnapping of four expatriate oil workers from the EA Oil Field in Delta State provides a window into the nature of media coverage of the escalating crisis in the Niger Delta region. This study shows that conflict reporting in the Nigerian press is 'episodic', featuring such conflict behaviours as the bombing of drilling platforms and oil pipelines, killing and maiming of oil workers and state security operatives, and kidnapping and hostage taking, which are the focus of this study. Framing of these conflict behaviours is influenced by ethno-political factors, foreign policy implications, and the height of drama of the situation. Drawing data from three national daily newspapers - The Punch, the Daily Champion and the New Nigerian - this work shows that the reporting by The Punch and the Daily Champion indicated 'support framing' of the Niger Delta, while the New Nigerian showed 'distance framing'. The press, however, needs to reverse the practice of 'describing' conflict situations through straight news stories and to focus on more analysis-based features and editorials that 'prescribe' solutions.
\end{abstract}

\section{Key Words:}

Mass media, hostage taking, Niger Delta, violence, framing.

\section{Introduction: The Nigerian Media and Conflict Coverage in the Niger Delta}

The Niger Delta of Nigeria has become the focus of interest of the press, both indigenous and foreign, not just for the high profile economic and industrial activities that go on there, nor for the oil exploitation and exploration, but for the crises, often of a violent and fatal nature, that take place there. The people of the oil-producing Niger Delta have often considered themselves to be marginalised - politically disenfranchised and economically impoverished in spite of being natives of the region that hosts Nigeria's petroleum oil and gas industries, which account for more than 80 percent of the nation's Gross National Product (Dode, 2011). 
Although the agitation in the region has been predicated on the claims of injustice, inequity and the neglect of the area and exclusion from the benefit of oil wealth, media coverage has often excluded the issues in the conflicts and focused mainly on what Umaru Pate refers to as "conflict behaviours" (Pate, 2002, p.141). These conflict behaviours include clampdowns on, and closures of, oil installations, bombing of oil wells and drilling platforms, kidnapping of oil workers or other forms of abduction, killing and maiming of oil workers and security operatives, and also inter- and intra-community feuds. Levi Obijiofor (2008) has observed that media reports on the Niger Delta are largely 'episodic' and 'sporadic'. He notes perceptively:

"If there are no explosions, no abductions, no shootings and no killings in the Niger Delta cities, the region would most certainly disappear from the radar of journalists. But the moment a school child is kidnapped in Port Harcourt or Warri or Yenagoa, the media would encircle that city and cover the event until it loses currency or until another event breaks out in the region or elsewhere."

This research indicates that the sporadic coverage of the crisis is informed by the Nigerian media's concept of news value, the height of the drama, media ownership, and logistic challenges of accessing the swampy sites of conflict in the Niger Delta and consequent overdependence on official government sources for news information. Nwagbara (2010, p.19) sketches the scenario by stating that "the wake of partisan journalism, sponsored news programmes, commercialised media enterprise, political reporting, and propagandistic reportage" have created a grotesque picture of information dissemination in the Nigerian media, especially in its coverage of conflict. The Nigerian media, therefore, serve not only as chroniclers of violent crises; they also do so from the perspective of government sources, who are constantly seeking to control information flow for the benefit of the ruling elites.

However, dissenting groups in the Niger Delta have found a way of invading media space given the prolonged stifling of their voices. This is done through peaceful protests or violent crackdowns. Often placard-carrying men, women and youth are seen in government buildings demanding one thing or another - from friendlier environmental practices among oil companies to improved welfare packages as compensation for the impact of oil exploration on their lives and communities. On the other hand, masked gun-toting young men invade oil facilities leaving destruction, pain and death in their train - these are automatically reported. It has become fashionable for some dissenting groups to claim responsibility whenever such 
attacks occur and to use the incidents as a basis for threatening further attacks if the reason for the initial attack is not addressed as desired. This is evident in the claims of responsibility for incessant attacks on oil installations and the frequent kidnap of oil workers, especially expatiates, in the Niger Delta. The Movement for the Emancipation of the Niger Delta (MEND) is a typical example here as illustrated in this report:

"We wish to restate our warnings to oil companies still operating in the Niger Delta, and more especially, workers of such companies, to leave while they can. Our halt in attack was more of a tactical suspension which has come to its end. At a time of our choice, we will resume attacks with greater devastation and no compassion on those who choose to disregard our warnings" (The Punch, April 20, 2006, pp. 1-2).

Perhaps the most significant factor affecting conflict reporting in the Niger Delta is the concentration of much of Nigeria's mainstream media in Lagos, the nation's commercial capital in south-west Nigeria. This singular factor has implications for effective conflict coverage: first is that the capitalist world-view of the city rubs off on every activity as bottom-line (profit) considerations influence every decision, including news judgements. So a newspaper proprietor that is operating from Lagos prioritises profit over public service. Hence, news judgement is predicated ultimately on the promise of pecuniary returns. This is equally applicable to media outfits owned by media entrepreneurs of Niger Delta origin. Second, as mentioned earlier, the distance between Lagos and the Niger Delta creeks and the logistic challenge this poses is a limiting factor to effective coverage of conflict in the area. Journalists are therefore quick to choose the easy way out. They use press statements from official government sources or publish emails from militant leaders who seek to invade media space by the "back door" (Liebes and Kamp, 2004, p.79).

Closely linked to the problems of ownership and geographical location of newspapers in Nigeria is that of ethnic and political division in the country. In an elaborate work on the divisive role of the Nigerian media in the nation's early democratic history, a Nigerian media historian has noted that the newspaper industry in the first republic was "fiercely partisan," and it played "inciting and exacerbating" roles in the violent crisis that truncated the first republic (Ishola, 2008, p. 120). Apparently, the same situation extant in the first republic plays out in current reportage of the crisis in the Niger Delta as the mainstream media are lethargic in their coverage of the region, investing only a limited amount of resources in their coverage of the region. The Nigerian media, therefore, essentially depend on what Oscar 
Gandy refers to as "information subsidies" where political actors "attempt to produce influence over the actions of others by controlling their access to and use of information relevant to those actions" (Gandy, 2007, p.75). This work shows how hostage takers in the Niger Delta and government forces exert this control.

\section{Research Objectives, Materials and Method}

By focusing on anarchy and mayhem at the expense of the real issues in the Niger Delta crisis, the media may be creating panic and a perpetual atmosphere of fear; thus serving the interest of the 'terrorist'. More so, when journalists sensationalise conflict by focusing on the drama of violence narrated in inverted pyramid-style stories, the media miss an opportunity to contribute to conflict resolution. This paper, therefore, employs the content analysis method to examine the reporting of hostage taking in the Niger Delta as captured in three Nigerian newspapers - The Punch, the Daily Champion and the New Nigerian. The incident in focus is the abduction of four expatriate oil workers in the Niger Delta on January 11, 2006. This paper is designed to achieve the following objectives:

- Determine the level of prominence given to the coverage of hostage taking crisis in the Niger Delta in the newspapers under review.

- Examine the overt patterns in the use of language that may portray the press as taking sides in their reporting of hostage taking in the Niger Delta.

- Establish the images of the Niger Delta militia the Nigerian press portrays.

- Determine the factors that may be responsible for the patterns of coverage of the hostage taking crisis in the Niger Delta.

In this work, the quantitative approach (frequency) is used to answer questions on the size and prominence of the coverage of the January 11, 2006 hostage taking of four expatriate oil workers in the Niger Delta. On the other hand, the qualitative approach (non-frequency) provides answers to questions on the framing of the hostage taking saga. It is also to show how the manifest language of the text reflects sympathy for or apathy towards the Niger Delta cause and the image given to the hostage taking incident by the newspapers under review.

This approach is considered appropriate because it allows for a qualitative analysis of media content according to prescribed rules of language and editorial performance. In-depth analysis reveals overt patterns in political discourse in news stories (including their 
headlines), features, letters to the editor, advertorials, and opinion articles. Wimmer and Dominick (2004, p. 138) affirm the practicability of the content analysis method for the examination of media contents, especially for the assessment of what image the media makes of "certain minority or otherwise notable groups" in a plural society.

The three newspapers selected for this paper are The Punch, the Daily Champion, and the New Nigerian. The Punch was taken for its wide readership. It prides itself as being "the most widely read newspaper." It has a national scope in its content coverage and copy distribution. Although it enjoys national acceptance, The Punch, which is based in western Nigeria has an, albeit subtle, western bias.

The New Nigerian was selected to represent the northern perspective. It enjoys the favour of the northern elite and covers national issues from a pro-Northern perspective. Of its editorials, the force and gut of the New Nigerian is so strong that it could not be ignored (Okoye, 2003). It is thought to be written by the cream of the conservative intelligentsia and academia in the north. The paper, therefore, does not enjoy a national readership. It is about the only paper in the country that is dependent on the Federal Government for funding.

The Daily Champion represents the eastern perspective. It is published simultaneously in Lagos and in Owerri. A cursory reading of the paper reveals its unequivocal eastern (specifically, Igbo) bias. The Daily Champion was chosen to represent the eastern perspective on the issue of hostage taking in the Niger Delta, and this was especially because of its being based, though partly, in Owerri, South-East Nigeria.

\section{Media Construction of Hostage Taking in the Niger Delta}

Four expatriate oil workers were reportedly kidnapped from the EA Oil Field in Delta State, Nigeria, on Wednesday January 11, 2006 by a hitherto unknown group that came to be identified as the Movement for the Emancipation of the Niger Delta (MEND). The hostages were held for 20 days and released on Monday January 30, 2006. This work shows how The Punch, the Daily Champion, and the New Nigerian captured this incident during the three months of January to March 2006.

Table 1

Content Categories of the Reportage of the January 11, 2006 Hostage Taking 
in The Punch, Daily Champion and New Nigerian

\begin{tabular}{|c|c|c|c|c|c|c|}
\hline \multirow{2}{*}{ Papers } & \multicolumn{5}{|c|}{ Content Categories } & \multirow{2}{*}{ Total } \\
\cline { 2 - 6 } & News & Features & Editorials & Opinion & Letters & \\
\hline The Punch & 30 & 1 & 2 & 2 & - & 35 \\
\hline $\begin{array}{c}\text { Daily } \\
\text { Champion }\end{array}$ & 13 & 1 & 2 & - & - & 16 \\
\hline New Nigerian & 8 & 2 & & 2 & & 12 \\
\hline
\end{tabular}

As shown in Table 1, there was a total of 35 editorial entries on the January 11, 2006 hostage taking incident in The Punch during the three months under review. There were also 16 entries in The Daily Champion and 12 in the New Nigerian. A number of factors could be responsible here. First, The Punch is a more robust paper in terms of the number of pages. The Punch has a daily average of 72 pages. The Daily Champion and the New Nigerian average 48 pages, each, daily.

Table 2

Distribution of Prominence Given to Hostage Taking Reports

\begin{tabular}{|c|c|c|c|}
\hline Prominence & The Punch & Daily Champion & New Nigerian \\
\hline Front Page & 13 & 7 & 2 \\
\hline Inside Cover & - & 1 & - \\
\hline Back Page & 1 & - & - \\
\hline Centre Spread & - & - & - \\
\hline Editorial Page & 3 & 2 & 10 \\
\hline Other Pages & 18 & 6 & 12 \\
\hline Total & 35 & 16 & - \\
\hline
\end{tabular}

As shown in Table 2, of the 35 story entries on hostage taking in The Punch in the period under review, 13 stories or 37\% made it to the front page. In the Daily Champion, of the 16 entries, 7 (or 44\%) were front-page stories, and in New Nigerian, out of 12 entries, 2 (or 16\%) were front-page stories. Both The Punch and the Daily Champion also had one back page and one inside-cover story. This paper shows that in the New Nigerian, apart from the two front-cover stories with headlines "How he (the Sar'dauna) foresaw Niger Delta crisis" 
(January 16) and "Kidnapped oil workers regain freedom" (January 31), all other stories were tucked away in less significant pages. The data also show that in The Punch, 17 entries (34\%) were given half of the pages in which they appear. In the Daily Champion, 4 entries (or 25\%) had at least half of the page, while in the New Nigerian, 2 stories (or 17\%) enjoyed up to half a page.

This paper also reveals that out of the 35 entries in The Punch 26 (or 74\%) were direct references to the hostage taking crisis. The other 9 were indirect references or allusions to the problem. In the Daily Champion 12 entries (or 75\%) were direct references while 4 (or 25\%) were indirect. Again we see a more vigorous effort at reporting the Niger Delta problem by the Daily Champion. This is closely followed by The Punch as the New Nigerian trails behind.

\subsection{Defining Prominence in Crisis Reporting}

Crisis reporting is the process by which the press documents a crisis for transmission to a mass audience. Going by Harrison's position that news aims at "producing the report of an event, but not the experience of event," (Harrison, 2006, p. 11) it is obvious that the newspapers spent more efforts describing the crisis than prescribing or suggesting a solution. Harrison suggests further that while the news uses facts and figures to tell a story 'as it is found' (2006, p. 11), features, like other editorial materials, investigate and appraise facts and figures to the purpose and intent of drawing significances, contexts, and implications from events and phenomena.

Norman Fairclough (2003) has identified two roles the news plays in capturing social reality. One is "referential intentions" which is the narration of events; the other is "explanatory intentions" which he defines as an attempt "to make sense of events by drawing them into a relation which incorporates a particular point of view." News in these contexts is at best descriptive, painting factual pictures of events for the reading pleasure of a waiting audience. The Niger Delta crisis requires more than mere description. It requires that the press is more proactive in seeking ways and means by which it can contribute to the resolution of the crisis. While this is not an advocacy for a swap in the statistics described above, the argument of this work is that the need for more commentaries in the form of features, editorials and opinions is most compelling, and the potential of the press in this respect is enormous. 
This study shows that the papers gave a high level of prominence to the hostage taking crisis in the Niger Delta. A number of reasons may be adduced for this pattern. First, the problem was not just a national one. It was international in many respects. The four hostages were foreign nationals - American, British, Honduran, and Bulgarian. The pressure from their home governments and other members of the international community was palpable. Apart from the fact that the abduction of the oil workers brought a halt to production at the oil field, hostage taking was only a part of a composite strategy to halt the oil export capacity of Nigeria. For the rest, the strategy consisted of attacks on pipelines and flow-stations, the undermining of the security of the entire Niger Delta, and inter- and intra-community feuds. This has entailed an unprecedented rise in the petroleum price in the international oil market.

Another reason that quickly emerges for the level of prominence accorded the hostage taking stories is the implication of the crisis for Nigeria's national life. It is estimated that the Niger Delta accounts for between 85 and 95 percent of the nation's wealth. Any activity therefore that is geared towards frustrating or undermining the economic potential of the nation must be of the greatest interest to the press. During the period under review, The Punch in its April 26, 2006 edition stated that "separatist guerrillas have carried out series of attacks on oil facilities, forcing foreign multinationals to cut Nigeria's exports of around 2.5million barrels per day by around a quarter." This has taken the price of crude to an unprecedented high of around \$65 per barrel.

Apart from the national and international implications of this hostage taking incident, the 'threshold of drama' that the incident brings to the news arena heightens its news value. The drama that is created by a group of young people armed with sophisticated weapons, attacking and sometimes overpowering national security agencies is of the greatest interest. Then, the utter inaccessibility of the creeks in which the hostages are held and the anxieties across the globe for their well-being were in themselves sufficient to keep the news media busy with updates the waiting audiences were desperate to read.

\subsection{Deconstructing Objectivity and Bias in Crisis Coverage}

This work examined selected texts from the coverage of the hostage taking to determine the overt feelings that were portrayed in the reports. In doing this, it was important to observe the caveat proposed by Adrian Beard (2001, p. 3) that: 
"there is no such thing as absolute, objective reality. All use of language involves the language user and the language receiver in a relationship - and relationships are complex things, viewed differently by all involved...Texts are produced by authors who live in the political and social world... and we gain a better understanding of their works by taking these contexts into account."

While this work agrees with Beard's views on the impracticability of absolute objectivity, especially in political communication, it must be noted that the press can at least strive towards neutrality in conflict reporting. The following headlines may help in supporting this point. In the New Nigerian, the headline "Oil workers kidnapped in Niger Delta" appears more hostile than that of The Punch's "Naval Chiefs relocate to Bayelsa over hostages" and the Daily Champion's "Shell attacked, 4 kidnapped," all of which appeared on the same day, January 13. The New Nigerian appears more forward in locating the action in the Niger Delta than the other papers. The Punch seems more interested in highlighting the solutions to this crisis, hence its choice to emphasise the efforts of naval chiefs at relocating to the location of the crisis - Bayelsa - in order to find strategies for solutions. In the Daily Champion, Shell is "attacked" and four persons are "kidnapped," but the culprit is not mentioned, nor is the location stated.

Apparently, language "reflects the ideological position of those who have created it and how the ideological position of the readers will affect their responses too" (Beard, 2000, p. 15). The following headlines from the three newspapers under review further illustrate the point:

"Niger Delta Youths Warned"

"Niger Delta: Militants Deserve Military Action" (New Nigerian)

"FG Begging Talk with Militants"

"Hostages: FG Strikes Deal with Militants" (The Punch)

"Why We Take Hostages - NDPVF"

"Niger Delta: Gani Cautions against Invasion" (Daily Champion)

In the first set of headlines, the call for military action is blatant. In the second set, the paper assumes the role of a convener, negotiator, and dialogue manager. In the last set of examples, we see the paper offering a 'voice' to the militants. They even overtly place the militants in 
the vantage position of co-contenders for control of the apparatus of state. These perspectives are informed by the selectivity of journalism as fitly stated by Brian McNair (2005):

"Journalism is selective, as we have seen, simply because any account of reality has to sample from the chaos of events, and focus on some aspects rather than others. In so doing, journalism highlights and draws attention to some events, processes and accounts while ignoring or downplaying others... and for this reason, journalism is more than the simple provision of information. It has always been ideological and deeply political" (p.35).

Corroborating, Piers Robinson (2002, p. 28) discusses how this ideological influence affects the framing of news stories. He identifies two ways. The first is "distance framing" which is a style that "creates emotional distance between the audience and the people suffering in a crisis." The other is "support framing," a style that does basically the opposite creating identification with, and empathy (by the audience) for, those suffering in a crisis.

Looking at the first story that announced the January 11 abduction of the oil workers, the following excerpts taken from the January 13 edition of the three papers are revealing. In The Punch front page, the report on the abduction of the four oil workers is appended to another story where Shell is reducing production by "226,000 barrels of oil per day" as a result of attacks on its Trans-Ramon pipeline, Brass Creek manifold in Bayelsa State". The report goes on to highlight other losses as a result of cuts in the production capacity of the oil-rich region. Not until the eighth paragraph is a mention made of the attack: "Four foreign oil workers - a Briton, an American, a Honduran and a Bulgarian were kidnapped by an armed gang at the offshore oil-field belonging to SNEPCO. Reports stated that the kidnappers shot their way through before seizing the workers [my emphasis]" (p. 2).

Clearly, The Punch is not in a hurry to name the attackers who are twice referred to as an "armed gang" and "kidnappers" unlike the other papers that quickly identify the culprits, often by the generalized appellation 'Niger Delta Youth'. The Punch maintains the anonymity of the attacker. The usual stereotyping expression "Niger Delta Youth have attacked ..." is absent here. This fact is subtly portrayed in this report showing a substantial level of 'support framing' (Robinson, 2002, p. 28). Although the report is vigorous in highlighting the volume of loss due to the attacks, it does not bring the 'culprit' into direct confrontation with the audience by 'distance framing'. In its front page reporting on the issue, 
the Daily Champion follows a related line except that it quickly applies the tag of "terrorism" to the attacks. Its January 13 report of the kidnapping opens with the line "A new dimension to oil pipeline terrorism emerged in the troubled Niger Delta... [my emphasis]."

The phrase "pipeline terrorism" is actually a new one replacing the usual "pipeline vandalism." Such use is likely to make a distinction between this act of destruction and the usual drilling of oil pipelines to steal petroleum products. It may also have been used to describe the quantum of damage experienced in pipeline bombing, an attempt to create mutual loss to the state and to the 'vandals'. This contrasts with the usual minor sabotage of oil pipelines which, though it represents a loss to the state, is a gain to the perpetrator.

In addition, the phrase "troubled Niger Delta" may be seen as stereotyping. Strictly speaking, at this time, much of the crisis - especially kidnapping - is located in certain riverine villages in Bayelsa and Delta States. To generalize one crisis to the entire Niger Delta region may be tantamount to labelling. Scholars agree that it is common for elitist-oriented media to label dissenting groups, often in an attempt to bring them to disrepute (Zelizer and Allan, 2004, p. 26).

In its report of the January 11 kidnap, the New Nigerian presents many interesting features. The opening paragraph of its January 13 issue says, "Four foreign oil workers have been kidnapped in southern Nigeria" (p. 8). Here, the culprit is highly generalised to the whole of "southern Nigeria." To the New Nigerian, if it is not in the north, then it is south. These are the only two divisions there are in Nigeria. Although there are six defined geopolitical zones in the country, the north (dominated by the Hausa/Fulani extraction) has continued to view the sharing of political power on the basis of the north and south divide, a position that favours the dominant groups to the detriment of the minority groups in the north. This generalisation of the kidnapping incident to the entire southern Nigeria to a large extent reflects "distance framing". Another excerpt from this report reads, "Such attacks are common in the Niger Delta region, where local groups complain they do not see the benefits of the area's oil wealth." (p. 8)

In the phrase, "such attacks are common" may be seen as another example of labelling. There is also the shift from the usual "claim" to the rather distasteful "complain" in the phrase "...local groups complain...." In this clause, the New Nigerian maximises Fairclough's 
"explanatory intention" of determining news value through what he calls "focalisation", which is the process of making sense of events by "drawing them into a relation which incorporates a particular point of view" (2003, p. 85). In this report, the New Nigerian presents its position on the agitations of the Niger Delta as mere 'complaints' which may be unfounded on facts, after all.

Another story that featured in the three newspapers is that of the release of the hostages on Monday January 30, 2006. The story appeared in the Tuesday January 31 edition of the papers. On The Punch front page, the story came with the headline, "Leave now, militants warn foreign oil workers." Then, a rider which appears on top of the photograph of the freed hostages reads, "Free! ... After 20 days in captivity!" In Daily Champion, "Hostages Freed! Obasanjo talks tough" was the screaming headline. Then, the New Nigerian had it as "Kidnapped oil workers regain freedom".

One thing is common here. There is a deliberate intention to report the freedom of the hostages apart from the effort of the kidnappers. The Punch in its characteristic manner, as observed in this study, deflects attention from the hostages to the new moves of the militants - their fresh threat to attack foreign oil workers. Then, the rider "Free ... after 20 days" does not say who is doing the freeing. A similar tone is presented in the Daily Champion where the "Hostages [are] freed" without anyone doing the releasing. This is immediately followed by "Obasanjo talks tough", an addition which may be interpreted as being derisive of the President. This interpretation is based on the premise of a decline of public confidence in the capacity of government to go beyond talk in addressing the nagging socio-economic challenges facing the country.

In the New Nigerian, the action is located with the hostages who "regain freedom." It does appear that they fought for and won their freedom. All along, the action of releasing the hostages is withdrawn from the kidnappers and either left neutral or given to the victims. This is because by the simple principle of semiotics, the sign "terrorist" cannot go with the sign "liberated." This, as early newsman and communication scholar James Hartley (1982) has suggested, is because the negative sign "terrorist" cannot go with a positive sign "liberated." It can only combine with "captured," "over-ran," or "occupied." 
However, in crafting its front page report, The Punch nearly defies this rule of social discourse. This exception could not be sustained beyond the first clause. In the second clause of the same sentence, it reverts to the rule. The report reads as follows: "Militants in the Niger Delta released the four kidnapped foreign oil workers on Monday, warning that further attacks on oil installations should not be ruled out."

Meanwhile in the two succeeding paragraphs, The Punch does some positive imaging for the kidnappers as the following excerpt shows, "The militants advised all expatriate workers in the region to leave because they might not be as lucky as the freed hostages...The release of the hostages was done purely on humanitarian grounds and no request was made for money" (p. 2).

Citing an email sent to Agency France Press (AFP), The Punch gave the first five paragraphs to voice the position of MEND and to highlight the militant group's next line of action. Liebes and Kampf (2004, p. 82) have argued that this kind of focalisation "amounts to providing unpaid advertising to terrorists, a service that would never be giving to domestic political leaders." This study, however, shows that the remaining 25 paragraphs of this story present the official view of government on this issue - with simple reiteration of official statements that contain references to the militants as 'criminals' and 'terrorists'.

On their part, the Daily Champion and the New Nigerian approach the story from the point of view of the government. The Daily Champion opens its front page story as follows: "After 19 days in captivity, the kidnapped oil workers were freed yesterday by Ijaw militants. They were handed over to ...." One point stands out here, that although the action of the handover is located with the militants, it is rendered in the passive voice "by Ijaw militants" and that is very significant. The report seemed to be unwilling to locate any approving statement with the kidnappers. It needs also to be stated that the term "Ijaw militants" is also a shoddy generalisation because at the time of filing the report the identity of the kidnappers had been sufficiently established.

In its scanty four-paragraph report of the release of the hostages, the New Nigerian spends more time reporting the threat of the President to treat any hostage-taking group "as a terrorist organisation" than on reporting the release. The report is unabashedly tilted to the side of the government. No backgrounds on the labelling phrase "Niger Delta militants" nor on the 
hostages whom the other papers described with such details as their personalities, their experience as hostages, and the reactions of their families and home governments to their release. The New Nigerian was also sketchy about the process of the release and the eventual handover to government authorities, which was copiously reported by the other papers. The New Nigerian also states that the militants had demanded a ransom of $\$ 2.5$ billion. It does not say whether the money was given or not. While the Daily Champion is completely silent about any ransom being paid, The Punch alludes to the fact that $\$ 60$ million may have been paid of $\$ 120$ million that was demanded as ransom.

It may, therefore, be inferred from these reports that the New Nigerian exhibited an unrestrained bias in the reporting of hostage taking in the Niger Delta, although its support for the government's side does not seem apparent either. On their part, the duo of The Punch and the Daily Champion are more vigorous in presenting the two sides of the picture - the government's view and that of the dissenting group. It is also clear that, in using attribution, a group is often favoured in the news if it is allowed to speak. It is only natural that a group will try to present itself in the best light possible. Hence, every opportunity to be heard is exploited maximally. By the process of selection, reporters and editors often choose which side in a conflict to favour. Although they may be reporting the facts, reporters often choose what 'facts' to report. This is in line with Hugo de Burgh's position that "news does not simply reflect reality, it helps create it. It is also selective" (2000, p. 75).

Further, regarding the image created of the Niger Delta militia in the Nigerian press, The Punch, in a February 01, 2006 editorial titled "worsening insecurity in the land", describes the crisis in the Niger Delta as one of the many pockets of agitation, most of them violent, across the land. In this way, the Niger Delta is not singled out as the only troubled region in the country. There is no name-calling. Instead, the generic expression "youth violence in the Niger Delta" is used to describe the agitation. The Punch also identifies with the "poverty, injustice and unemployment" plaguing this region and names these as the factors fuelling the crisis.

Clearly, it can be inferred that The Punch is portraying the Niger Delta militia as a group packaging, presenting and venting the frustrations of a people affected by many years of neglect and marginalisation, in spite of living in the midst of vast oil wealth and suffering the effects of the exploitation of the same. The Punch in that editorial rather puts the blame on 
the government and its agencies beleaguered by "economic, social and political contradictions which are at the root of the festering insecurity in the country" (p. 16).

On its part, the Daily Champion published an editorial that is more directly focused on the "Hostages in the Niger Delta." While it also identifies with the plight of the region, it faults the strategy of holding on to foreign nationals, pointing out the adverse political and diplomatic implications of doing so. The Daily Champion focuses on identifying the negative impact of oil exploration on the Niger Delta people - [air] pollution, acid rain, the mass dislocation of local populations due to oil spills, and general man-made poverty of a political nature - the cause for which the militia is fighting. Apparently, the Daily Champion portrays the Niger Delta militia as fighting for a legitimate cause, although it is unequivocal in denouncing the option of violence.

On the other hand, the New Nigerian had no editorial commentary on this issue during the period under review. However, in its January 13 story cited earlier, the paper commented that "such attacks are common in the Niger Delta region where local groups complain they do not see the benefits of the area's oil wealth." This report seems to suggest that the attacks are unprovoked, and unwarranted. Thus, the fighters are just frustrated and disgruntled hooligans who want to unsettle the state.

This fact is further emphasised in the choice of the angle of reporting of the January 30 story captioned "Niger Delta youths warned." In this report, the youth in the Niger Delta are described as "lawless", and "misled" into confronting constituted authority. The event in the story is the commissioning of the Abuja liaison office of the Ministry of Defence HIV Programme by the then Minister of State for Defence, Dr. Rowland Oritsejafor. However, the reporter chose a comment made by the junior minister on the Niger Delta crisis and anchored the story to it. It is to be inferred that the New Nigerian is committed to highlighting the negative side of the Niger Delta struggle and the participants in that struggle.

It is insightful to note that all three papers investigated in this study gave their first report of the January 11 hostage taking on January 13, two days after the abduction of the workers. The reasons for this are obvious. The papers would have needed the 12th to collect the information, file the reports, and be ready for the news-stand on the 13th. The broadcast media may have aired it earlier. 
Considering the area where the hostages were taken, it may have been difficult to access information given the logistic challenge imposed by the environment. Water transportation is required to access the creeks, and the enabling facilities are not up-to-date or fit to support easy access. Besides, the security risk associated with such an expedition is steep. More so, the sheer unexpectedness - the unpredictability and rarity - of the event, which heightens its news value, may have contributed to the delay in reportage. This factor imposes a state of shock and chaos even on the authorities who need time to understand and appreciate the situation, ascertain the extent of damage, and determine further threat potentials before briefing the press.

On the issue investigated, The Punch entered 30 news reports (86 percent of the 35 items of editorial material featuring the crisis). The other five items (14 percent) comprised one feature article, two editorials and two opinion articles. In the Daily Champion, the thirteen news items examined for the period under review constituted 81 percent of the sixteen editorial entries made on the January 11 incident, while one feature article and two editorial articles accounted for 19 percent of other editorial content. In the New Nigerian, there were seven news items (or 78 percent of the editorial material reviewed) while the other two (or twenty two percent) were opinion articles. The conclusion of this paper, therefore, is that the ratio of news reports to other editorial materials is too heavy on the news side.

\section{Conclusion}

This study was designed to examine the reporting of the January 11, 2006 kidnapping of four expatriate oil workers in the Niger Delta in three Nigerian newspapers. The objectives were to determine the level of prominence given to the coverage of the hostage taking, examine the patterns in the use of language that may portray the press as taking sides in their reporting of hostage taking, establish the images of the Niger Delta militia the Nigerian press presents, and determine the factors that may be responsible for the patterns of coverage.

The study also shows that the level of prominence each newspaper gave to the hostage-taking incident was predicated on the political orientation of the press. While The Punch and Daily Champion (both based in the south) gave significant prominence to the story, The New Nigerian (a pro-north newspaper) conferred less status on the issue. This study has shown that The Punch and Daily Champion featured 35 percent and 44 percent respectively of news stories on the incident on their front pages. The New Nigerian featured 16 percent of its 
entries on the front page. In addition, while The Punch had three editorial comments of the issue, the Daily Champion had two and The New Nigerian had none. It may be inferred, therefore, that the two south-based newspapers showed a higher commitment to an agenda on the Niger Delta conflict than the north-based paper.

It is also pertinent to state that the factors that accounted for the level of prominence accorded the hostage taking crisis include: (a) the impact of the incident on Nigeria's foreign policy, as foreign nationals were the abductees; (b) the implications for international trade as the incident had a direct impact on the pricing of oil in the international market; (c) the impact on the local economy, since the crisis was at the core of the nation's source of economic sustenance - the oil; and (d) the threshold of drama enacted as armed youth engaged the constituted military authorities of a sovereign nation. While the prominence given may help in calling global attention to the plight of the Niger Delta people, this work has shown that it does have adverse effects on the image of the region presented to the world with grave political and diplomatic implication for the nation at large.

This paper also shows that the ethno-political biases that are present in Nigeria played out in the newspapers' reporting of the hostage taking crisis. This is manifest in the use of labelling, stereotyping and news angle. Thus, while the south-based papers portrayed the Niger Delta agitation (as reflected in hostage taking, pipeline vandalism and acts of violence) as selfdetermination given the years of neglect and impoverishment of the oil-rich region, the northbased paper portrayed it as 'lawlessness' which should be crushed. In essence, The Punch and Daily Champion promote the marginalisation rhetoric of the Niger Delta people, while the New Nigerian portrays them in the light of a disgruntled lot threatening the corporate existence of the nation.

Meanwhile, the over-dependence of journalists on government sources and press releases issued by dissident groups limits the ability of journalists to capture the ramifications of the conflict. Logistic challenges imposed by the swampy environment and the security risk account for this limitation. More so, as in most stories of conflict, the sheer threshold of drama and the anxiety created in society forces reporters and editors to constantly churn out breaking news and updates, leaving little room for in-depth analysis of the issues in the crisis. This results in the heavy tilt of editorial content towards news which only goes to 'describe' the situation rather than 'prescribe' solutions. An increased number of editorials, features and 
opinion articles, objectively analysing the issue and offering solutions would be appropriate and is hereby recommended. This will help in not only ending the spate of kidnapping in the Niger Delta, it will also foster efforts at stemming other acts of violence and create the environment for sustainable peace and development in the region.

\section{References}

Beard, A. 2000. The language of politics. London: Routledge.

Beard, A. 2001. Text and context: Introducing literature and language study. London: Routledge.

Boyd-Barret, O. 2004. Understanding the second casualty. In Stuart Allan and Barbie Zelizer (Ed.), Reporting war: Journalism in wartime (pp. 25 - 42). London: Routledge.

Burgh, H. 2000. Some issues surrounding investigative journalism. In Hugo de Burgh (Ed.), Investigative journalism: Context and practice (pp. 65-88). London: Routledge.

Dode, R. 2011. The political economy of resource curse and the Niger Delta crisis in Nigeria: Matters arising. Afro Asian Journal of Social Sciences, 2 (2.1): 1-15 [online]. Retrieved 10 March 2012 from http://onlineresearchjournals.com/aajoss/art/56.pdf.

Fairclough, N. 2003. Analysing discourse: Textual analysis for social research. London: Routledge.

Gandy, O. 2007. Beyond agenda setting: Information subsidies and public policy. In Ralph Negrine and James Stanyer (Eds), The political communication reader (pp. 75-78). London: Routledge.

Harrison, J. 2006. News. London: Routledge.

Hartley, J. 1982. Understanding news. London: Routledge.

Ishola, A. 2008. The role of the print media in the coverage of political crises in south-west Nigeria. [PhD Dissertation]. Peace and Conflict Studies Programme, Institute of African Studies, University of Ibadan, Nigeria. 
Leave now, militants warn foreign oil workers. The Punch, 20 April 2006: 1-2.

Liebes, T. \& Kamp, Z. 2004. The PR of terror: How new-style wars give voice to terrorists. In Stuart Allan and Barbie Zelizer (Eds), Reporting war: Journalism in wartime (pp.77-95). London: Routledge.

McNair, B. 2005. What is journalism? In Hugo de Burgh (Ed.), Making journalists (pp. 2543). London: Routledge.

Nwagbara, U. 2010. The Nigerian press. The public sphere and sustainable development: Engaging the post amnesty deal in the Niger Delta. Journal of Sustainable Development in Africa, 12 (3): 19. [online] Retrieved 10 March 2012 from http://greenwichcollege.academia.edu/UZOECHINWAGBARA/Papers/1533690/The _Nigerian_press_the_public_sphere_and_sustainable_development_Engaging_the_po st_amnesty_deal_in_the_Niger_delta

Obijiofor, L. 2008. Niger Delta, media coverage and conflicting signals. The Nigerian Village Square. [online]. Retrieved 10 March 2012 from http://www.nigeriavillagesquare.com/articles/levi-obijiofor/niger-delta-mediacoverage-and conflicting-si-2.html.

Okoye, I. 2003. The evolution of newspaper editorial writing in Nigerian journalism 19002000. In Ralph Akinfeleye and Innocent Okoye (Eds), Issues in Nigerian media history: 1900-2000 AD (pp. 10-17). Lagos: Malthouse Press.

Pate, U. 2002. Reporting conflict for newspapers and magazines in democratic Nigeria. In Umaru Pate Lagos (Ed.), Introduction to conflict reporting in Nigeria (pp. 133-142). Lagos: Friedrich Ebert Stiftung.

Robinson, P. 2002. The CNN effect: The myth of news, foreign policy and intervention. London: Routledge. 
Wimmer, R. and Dominick, J. 2004. Mass media research: An introduction. Belmont, CA: Wadsworth.

Zelizer, B. and Allan, S. 2002. When trauma shapes the news. In Barbie Zelizer and Stuart Allan (Eds), Journalism after September 11 (pp. 1- 24 ). London: Routledge.

\section{Chigozi Ijeomah Eti}

BA, Babcock; MA, Ibadan, PhD (in view) UPH)

Lecturer in Print Communication and Media Language

Department of Mass Communication

Babcock University

Ilishan-Remo, Nigeria.

Doctoral Candidate in the Communication Studies Programme

Department of Linguistics and Communication Studies

University of Port Harcourt

Choba, Nigeria

Email: chigoeti@gmail.com

Mobile: 234-803-570-4282 